\title{
Waste to resource: use of water treatment residual for increased maize productivity and micronutrient content
}

\author{
T. Gwandu (i) - L. I. Blake $\cdot$ H. Nezomba $\cdot$ J. Rurinda $\cdot$ S. Chivasa $・$ \\ F. Mtambanengwe $\cdot$ K. L. Johnson
}

Received: 8 March 2021 / Accepted: 10 September 2021 / Published online: 27 September 2021

(C) The Author(s) 2021

\begin{abstract}
Soil degradation, which is linked to poor nutrient management, remains a major constraint to sustained crop production in smallholder urban agriculture (UA) in sub-Saharan Africa (SSA). While organic nutrient resources are often used in UA to complement mineral fertilizers in soil fertility management, they are usually scarce and of poor quality to provide optimum nutrients for crop uptake. Alternative soil nutrient management options are required. This study, therefore, evaluates the short-term benefits of applying an aluminium-based water treatment residual (Al-WTR), in combination with compost and inorganic $\mathrm{P}$ fertilizer, on soil chemical properties, and maize (Zea mays L.) productivity and nutrient uptake. An eight-week greenhouse experiment was established with 12 treatments consisting of soil, AlWTR and compost (with or without $\mathrm{P}$ fertilizer). The co-amendment $\quad(10 \% \quad$ Al-WTR $+10 \% \quad$ compost $)$
\end{abstract}

T. Gwandu $(\bowtie) \cdot$ K. L. Johnson

Department of Engineering, Durham University,

Durham DH1 3LE, UK

e-mail: tariro.gwandu@durham.ac.uk

K. L. Johnson

e-mail: karen.johnson@durham.ac.uk

T. Gwandu $\cdot$ H. Nezomba · J. Rurinda .

F. Mtambanengwe

Soil Fertility Consortium for Southern Africa (SOFECSA)

Research Group, Department of Soil Science and

Environment, University of Zimbabwe, Mount Pleasant,

P.O. Box MP167, Harare, Zimbabwe

e-mail: hnezomba@agric.uz.ac.zw produced maize shoot biomass of $3.92 \pm 0.16 \mathrm{~g}$ at 5 weeks after emergence, significantly $(p<0.05)$ outyielding the unamended control which yielded $1.33 \pm 0.17 \mathrm{~g}$. The addition of $\mathrm{P}$ fertilizer to the coamendment further increased maize shoot yield by about twofold $(7.23 \pm 0.07 \mathrm{~g})$. The co-amendment $(10 \%$ Al-WTR $+10 \%$ C) with P increased maize uptake of zinc $(\mathrm{Zn})$, copper $(\mathrm{Cu})$ and manganese $(\mathrm{Mn})$, compared with $10 \% \mathrm{C}+\mathrm{P}$. Overall, the results demonstrate that combining Al-WTR, compost and $\mathrm{P}$ fertilizer increases maize productivity and micronutrient uptake in comparison with single amendments of compost and fertilizer. The enhanced micronutrient uptake can potentially improve maize grain quality, and subsequently human nutrition for the urban population of SSA, partly addressing the UN's Sustainable Development Goal number 3 of improving diets.

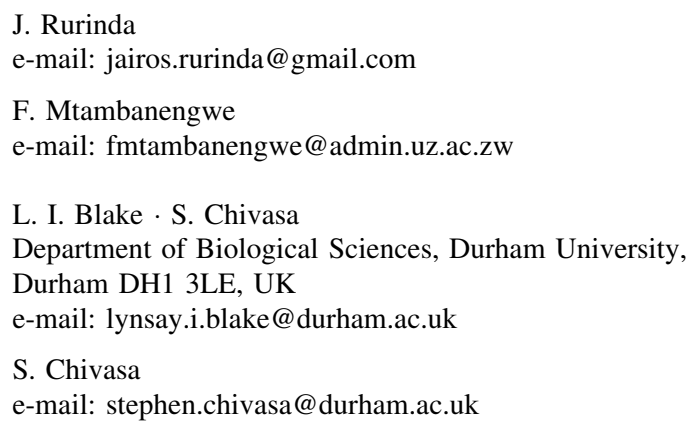


Keywords Aluminium-based water treatment residual · Organic nutrient resources - Mineral fertilizer - Soil chemical properties · Maize dry matter yield · Nutrient uptake

\section{Introduction}

There is growing concern over food and nutrition insecurity in the urban communities of Southern Africa, due to rapid human population growth coupled with limited job opportunities against limited livelihood alternatives (Awad, 2019; Cockx et al., 2018). To cope with these changes, many urban dwellers in the region are increasingly resorting to urban agriculture (UA) for household food, nutrition and income security (Kutiwa et al., 2010; Takavarasha, 2003). However, as is the case in many rural communities in Southern Africa (Kamanga et al., 2014; Mapfumo \& Giller, 2001), crop production has remained low in urban areas due to a combination of factors, including declining soil fertility (Mtangadura et al., 2017; Nyamasoka et al., 2015) and a changing climate (Rurinda et al., 2015), hampering efforts towards achievement of Sustainable Development Goals, most of which are underpinned by soil health (Keesstra et al., 2016; Lal, 2019). Without addressing poor soil fertility and the negative impacts of the changing climate, crop yields will remain poor, increasing the number of households vulnerable to food deficits.

Although mineral fertilizer is important for rebuilding soil nutrient stocks and increased crop productivity (Kihara et al., 2020; Rurinda et al., 2020), many farmers in SSA have limited or no access to mineral fertilizer due to high costs and inaccessibility. Current fertilizer application rates in SSA average only about $16 \mathrm{~kg} \mathrm{ha}^{-1}$. year ${ }^{-1}$, compared with over $100 \mathrm{~kg} \mathrm{ha}^{-1}$. year $^{-1}$ in Europe and North America and over $150 \mathrm{~kg} \mathrm{ha}^{-1}$. year ${ }^{-1}$ in China (FAOSTAT, 2019). To increase and maintain crop production in SSA, use of locally available organic nutrient resources is important (Mapfumo \& Giller, 2001). Organic nutrient resources increase crop yields by supplying plant nutrients in the short to medium term while improving soil organic matter and other soil physicochemical and biological properties in the long term (Mtambanengwe $\&$ Mapfumo, 2005). Farmers in rural areas of SSA rely on locally available nutrient resources such as partially composted woodland litter and livestock manure for crop production (Manzeke et al., 2012; Mapfumo \& Giller, 2001). In urban communities, crop residues from previous harvests are the most available organic nutrient resource because of little competition for their use as livestock feed. However, some farmers prefer to burn the crop residues due to the drudgery involved during their incorporation. Water treatment residual (WTR) is a potential organo-mineral resource that could be used for soil fertility improvement and soil health in UA, but its potential use remains largely untapped. WTR is a by-product of the municipal clean water treatment process, which is organo-mineral, containing aluminium ( $\mathrm{Al}$ ) and/or iron ( $\mathrm{Fe}$ ) oxides, activated carbon and flocculated material from reservoirs, including clay particles, mineral nutrients and organic matter (Elliot et al. 1990; Matilainen et al., 2010). WTRs can potentially contribute to soil carbon build-up in the long term because the organic matter becomes tightly bound in the $\mathrm{Fe}$ and $\mathrm{Al}$ oxide matrix (Elliott \& Dempsey, 1991; Novak \& Watts, 2004). When WTR is added to soil, the resultant soil organic matter (SOM) is adsorbed into the mineral matrix and is thus protected from microbial attack (Kögel-Knabner et al. 2008). On a global scale, it is estimated that 10,000 t of WTR, on average, are produced daily from standard water treatment works (Ahmad et al., 2016; Gibbons \& Gagnon, 2011). While information on WTR production trends from Africa is largely missing, given the rapid urbanization, more water will be purified to meet the increasing human demand, and inevitably more WTR will be generated. Since the WTR contains mineral nutrients and organic matter, it can, therefore, be used as an alternative source of soil nutrients including micronutrients for plant nutrition and soil health in UA. Use of WTR as a soil amendment can minimize costs of its disposal and the undesirable impacts on the environment.

Research has been done to understand the potential of WTR as a soil ameliorant (Dassanayake et al., 2015; Ippolito, 2015). Of major concern, however, is phosphorus $(\mathrm{P})$ dynamics following the addition of WTR to soil. Phosphorus is an important macronutrient in plant growth (Malhotra et al., 2018) and is one of the most limiting nutrients in the predominantly sandy soils of Southern Africa (Rurinda et al., 2020). Jonasson (1996) and Cox et al. (1997) demonstrated that $\mathrm{Al}$ or Fe oxides present in WTR potentially bind $\mathrm{P}$ in soil, making it unavailable for plant uptake. On the 
contrary, studies by Grabarek and Krug (1987), and Geertsema et al. (1994) have shown that the application of WTR to soil has no effect on P uptake and plant growth in tree species. Other reports (Mahdy et al., 2007; Rengasamy et al., 1980) have confirmed improved soil properties and dry matter yields of maize in fertilized and unfertilized pots amended with WTRs, albeit at certain threshold application levels. However, this also differed with soil type (Mahdy et al., 2007). Evaluating options that reduce the P-fixing ability of WTR would be key for sustainable use of WTR in crop production. Co-application of WTR with $\mathrm{P}$ fertilizer may eliminate the problem of $\mathrm{P}$ deficiencies for plant growth (Hyde \& Morris, 2004). Alternatively, co-application of WTR with compost or other organic plant or animal-based waste may help to alleviate $\mathrm{P}$ sorption by the $\mathrm{Fe}$ and $\mathrm{Al}$ oxides in soils (Havlin et al., 2005). Hsu and Hseu (2011) reported an increase in shoot biomass production of Bahia grass (Paspalum notatum) without changes in soil $\mathrm{P}$ availability due to co-application of WTR and pine bark compost. Recent work in Southern Africa has also proven that when WTR is used in combination with organic compost with a 1:1 co-application ratio, wheat (Triticum aestivum) productivity increased by $33 \%$ (Clarke et al., 2019). The resultant wheat growth was attributed to balanced nutrition, with $\mathrm{P}$ and potassium (K) from the compost and nitrogen $(\mathrm{N})$ from WTR. However, this has not yet been tested in maize (Zea mays L.), a strategic crop for food security in Southern Africa, including Zimbabwe. The overall hypothesis was that the application of WTR in combination with compost and $\mathrm{P}$ fertilizer improved soil chemical properties, maize nutrient uptake and dry matter yield relative to unfertilized maize. The objective of this study was to understand the effects of co-applying AlWTR, compost and inorganic P fertilizer, on soil chemical properties, and maize (Zea mays L.) productivity and nutrient uptake.

\section{Materials and methods}

Experimental set-up

An eight-week greenhouse pot experiment was set up

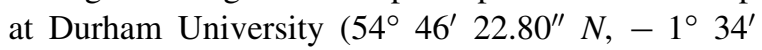
$26.40^{\prime \prime} W$ ), UK. The experiment consisted of 12 treatments as shown in Table 1.
A sandy-loam soil from Zimbabwe was used in the experiment. The soil is broadly classified as a Lixisol (WRB, 2006), exhibits low inherent fertility especially nitrogen $(\mathrm{N})$, phosphorus $(\mathrm{P})$, carbon $(\mathrm{C})$ and sulphur (S) and is characterized by low water holding capacity (Nyamapfene, 1991). Lixisols are prone to run-off and known to readily compact and crust under natural rainfall and are thus drought sensitive. This soil typifies most soils found in smallholder farming systems of Zimbabwe and most parts of Southern and West Africa (Nyamapfene, 1991; FAO.I. ISSS, 1998). A peat-based commercial compost used in this study was sourced locally in the UK. The Al-WTR was sourced from Carmoney Water Treatment Works, Northern Ireland. Al-WTR is also commonly available in Zimbabwe, where most water treatment works use aluminium sulphate (alum) in their water treatment processes. The physical and chemical characteristics of Al-WTR from Prince Edward waterworks (Zimbabwe) were comparable to the Carmoney Al-WTR. All the three materials (soil, compost and Al-WTR) were sieved to $2 \mathrm{~mm}$ for characterization of their physical and chemical properties and used in the pot trial.

The soil was limed to a target $\mathrm{pH}$ of 5.5 , which is favourable for maize growth. The different soil mixtures were incubated for three weeks during which they were watered to field capacity. After three weeks, they were then transferred into one litre PVC-plastic pots with perforated bases to allow free drainage of

Table 1 Experimental treatments

\begin{tabular}{ll}
\hline Treatment number & Treatment composition \\
\hline 1 & Control (Unamended soil) \\
2 & $10 \%$ Al-WTR \\
3 & $10 \%$ compost \\
4 & $20 \%$ Al-WTR \\
5 & $20 \%$ compost \\
6 & $10 \%$ Al-WTR $+10 \%$ compost \\
7 & Standard NPK (soil amended with NPK) \\
8 & $10 \%$ Al-WTR + P \\
9 & $10 \%$ compost + P \\
10 & $20 \%$ Al-WTR + P \\
11 & $20 \%$ compost + P \\
12 & $10 \%$ Al-WTR $+10 \%$ compost $+\mathrm{P}$ \\
\hline
\end{tabular}


excess water. The pots were arranged in a completely randomized design (CRD) with 6 replicates per treatment. One seed of maize variety SC513 (137 days to maturity), commonly grown in Zimbabwe, was planted in each pot. The greenhouse temperature was maintained at $24{ }^{\circ} \mathrm{C}$, and lighting was supplemented with artificial light set on a 16-h photoperiod for the duration of the experiment until harvest. Throughout the growth period, watering was done to maintain the soils' field capacity. For treatments with $\mathrm{P}$, a compound fertilizer, Compound $\mathrm{D}\left(7 \% \mathrm{~N}, 14 \% \mathrm{P}_{2} \mathrm{O}_{5}\right.$, and $7 \% \mathrm{~K}_{2} \mathrm{O}$ ) from Zimbabwe was used as a source of available $\mathrm{P}$ applied by spreading on soil and mixing-in to a depth of $5 \mathrm{~cm}$ before planting. Fertilizer rates were differentially applied across treatments based on the targeted $\mathrm{P}$ rates of $26 \mathrm{~kg} \mathrm{P} \mathrm{ha}{ }^{-1}\left(2.67{\mathrm{~g} . \mathrm{pot}^{-1}}^{-1}\right.$ for treatment 7 (standard NPK) and a target of $14 \mathrm{~kg} \mathrm{P} \mathrm{ha}{ }^{-1}$ (1.44 g.pot ${ }^{-1}$ ) for compost and WTR treatments, following $\mathrm{P}$ fertilization rates recommended by Mtambanengwe and Mapfumo (2009). Except for the unamended control (treatment 1), all treatments received additional $\mathrm{N}$ in the form of ammonium nitrate $(34.5 \% \mathrm{~N})$, as topdressing at a rate of $90 \mathrm{~kg} \mathrm{~N} \mathrm{ha}^{-1}$, and this was applied at 3 weeks after emergence.

Analysis of materials used in the experiment

The $\mathrm{pH}$ of the material was measured with $0.01 \mathrm{M}$ $\mathrm{CaCl}_{2}$ (Anderson \& Ingram, 1993) and readings taken using a standard pH meter (Hanna, H18424). Electrical conductivity (EC) was determined using the water extraction method and readings taken using the conductivity meter (Jenway470JCO2). Exchangeable bases $(\mathrm{Ca}, \mathrm{Mg}$ and $\mathrm{K})$ were extracted using $1 \mathrm{M}$ ammonium acetate (Anderson \& Ingram, 1993), whilst available $\mathrm{P}$ was extracted using $0.5 \mathrm{M} \mathrm{NaHCO}_{3}$ and all were measured using an inductively coupled plasma optical omission spectrometry (Agilent 5100 ICP-OES). Exchangeable acidity was determined through titration using phenolphthalein indicator. Total $\mathrm{C}$ and $\mathrm{N}$ were determined by combustion using flash 2000 organic elemental analyser. The metals, manganese $(\mathrm{Mn})$, sodium $(\mathrm{Na})$, zinc $(\mathrm{Zn})$, copper $(\mathrm{Cu})$, aluminium $(\mathrm{Al})$, iron $(\mathrm{Fe})$, magnesium $(\mathrm{Mg})$, calcium (Ca) and potassium $(\mathrm{K})$, were determined by X-ray fluorescence (XRF) via fused bead and wax pellet (Fitton, 1997).
Maize growth measurements, nutrient uptake and residual soil chemical analysis

Weekly measurements of plant height and number of leaves were conducted for five (5) consecutive weeks beginning on the 7 th day after emergence. Plant height was measured using a tape measure from the soil surface to the highest point of the arch of the uppermost leaf with its tip pointing down. The number of leaves was determined by physical counting based on the leaf tip method (Manitoba Crop Reports, 2020). The leaf tip method involves counting all leaves, including any leaf tips that have emerged from the whorl at the top of the plant. On the 35th day, maize plants were cut just above the soil surface to separate shoots and roots. Both the shoots and roots were washed in distilled water and left for 4 days under shade for air drying. After the 4 days, the biomass was oven-dried at $65{ }^{\circ} \mathrm{C}$ until a constant weight was reached. Total dry shoot and root biomass were then determined. The above-ground biomass (shoots) were ground to pass through a $2-\mathrm{mm}$ sieve using a magic bullet nutri-blender (EAN: 5,060,191,467,360) for determination of total N, P, K, Ca, Mg Cu, Mn, Zn, Al, $\mathrm{Pb}$ and $\mathrm{Ni}$. Total $\mathrm{N}$ was analysed using the Thermo Scientific Flash 2000 Organic Elemental Analyser, whilst $\mathrm{P}$ was extracted using the bicarbonate method (Olsen, 1954) and analysed using an ICP-OES (Agilent 5100). $\mathrm{Ca}, \mathrm{Mg}, \mathrm{K}, \mathrm{Cu}, \mathrm{Mn}, \mathrm{Zn}, \mathrm{Al}, \mathrm{Pb}$ and $\mathrm{Ni}$ were extracted using the microwave-assisted aqua-regia digestion method (Eskilsson \& Björklund, 2000) and concentrations read using the ICP-OES. Nutrient uptake is calculated with Eq. (1)

$$
\text { Nutrient } \begin{aligned}
X(\mathrm{mg} / \mathrm{kg})= & {\left[\begin{array}{c}
\left(X \text { concentration }\left(\mathrm{mg} \mathrm{l}^{-1}\right) / 1000\right) \\
\times \text { volume of the sample used }(\mathrm{ml})
\end{array}\right] } \\
& /[\text { sample weight }(\mathrm{g}) / 1000]
\end{aligned}
$$

where $X$ is $\mathrm{N}, \mathrm{P}, \mathrm{K}, \mathrm{Ca}, \mathrm{Mg}, \mathrm{Zn}, \mathrm{Cu}, \mathrm{Ni}, \mathrm{Mn}, \mathrm{Pb}$ or $\mathrm{Al}$.

For $\mathrm{N}, \mathrm{P}, \mathrm{Ca}, \mathrm{Mg}$ and $\mathrm{K}$ uptake was quantified in $\mathrm{g}$ $\mathrm{kg}^{-1}$, while for $\mathrm{Zn}, \mathrm{Cu}, \mathrm{Pb}, \mathrm{Ni}, \mathrm{Al}$ and $\mathrm{Mn}$ uptake was measured in $\mathrm{mg} / \mathrm{kg}$.

Chemical characteristics of the post-harvest soils were analysed as described in Sect. 2.2. 
Table 2 Chemical characteristics of soil, compost and WTR used in the experiment

\begin{tabular}{|c|c|c|c|c|}
\hline Parameter & *Soil & $*$ Al-WTR ${ }^{\mathrm{a}}$ & *Compost & European Community maximum limit ${ }^{2}$ \\
\hline Sand $(\%)$ & 73 & ND & ND & \\
\hline Silt $(\%)$ & 5 & ND & ND & \\
\hline Clay $(\%)$ & 22 & ND & ND & \\
\hline $\mathrm{pH}\left(0.01 \mathrm{~m} \mathrm{CaCl}_{2}\right)$ & 4.0 & 5.7 & 4.8 & \\
\hline $\mathrm{EC}\left(\mu \mathrm{S} \mathrm{cm}{ }^{-1}\right)$ & 80 & 872 & 2010 & \\
\hline Exchangeable acidity (meq/100 g) & 6.0 & 2.5 & 10.5 & \\
\hline $\mathrm{CEC}\left(\mathrm{cmol}(+) \mathrm{kg}^{-1}\right.$ & 6.5 & 31 & 84.3 & \\
\hline Total P (\%) & 0.06 & 0.12 & 0.10 & \\
\hline Available $\mathrm{P}\left(\mathrm{mgkg}^{-1}\right)$ & 6 & 5 & 261 & \\
\hline Total N (\%) & 0.03 & 1.28 & 1.28 & \\
\hline Total organic $\mathrm{C}(\%)$ & 0.47 & 18.37 & 46.9 & \\
\hline $\mathrm{C} / \mathrm{N}$ ratio & 15.7 & 14 & 36.7 & \\
\hline $\mathrm{Ca}(\mathrm{meq} / 100 \mathrm{~g})$ & 0.5 & 2.9 & 55.9 & \\
\hline $\mathrm{Mg}(\mathrm{meq} / 100 \mathrm{~g})$ & 0.3 & 0.2 & 12.5 & \\
\hline $\mathrm{K}(\mathrm{meq} / 100 \mathrm{~g})$ & 0.1 & 0.1 & 5.4 & \\
\hline $\mathrm{Pb}\left(\mathrm{mg} \mathrm{kg}^{-1}\right)$ & 4.1 & 17.6 & 7.5 & 750 \\
\hline $\mathrm{Cu}\left(\mathrm{mg} \mathrm{kg}^{-1}\right)$ & 0.4 & 45.7 & 5.7 & 200 \\
\hline $\mathrm{Zn}\left(\mathrm{mg} \mathrm{kg}^{-1}\right)$ & 0.5 & 203.8 & 35.4 & 400 \\
\hline $\mathrm{Ni}\left(\mathrm{mg} \mathrm{kg}^{-1}\right)$ & 5.1 & 41.0 & 2.8 & 150 \\
\hline $\operatorname{Mn}\left(\mathrm{mg} \mathrm{kg}^{-1}\right)$ & 29 & 4534 & 156 & ND \\
\hline $\mathrm{Al}\left(\mathrm{g} \mathrm{kg}^{-1}\right)$ & 1.2 & 15.2 & 2.2 & ND \\
\hline
\end{tabular}

ND-not determined

${ }^{\mathrm{a}} A l$-WTR aluminium water treatment residual; $E C$ electrical conductivity; $C E C$ cation exchange capacity

Data analysis

Analysis of variance (ANOVA) for a completely randomized design was used to analyse the effects of amendments on maize plant growth, nutrient uptake and post-harvest soil chemical properties using GENSTAT 19th Edition. Duncan's multiple-range test was then used to compare treatment means for all the measured parameters at $p<0.05$.

\section{Results}

Chemical characteristics of soil, Al-WTR and compost

The soil used in this study had high sand content (73\%), very low $\mathrm{pH}(4.0)$ and a relatively high exchangeable acidity (Table 2). The soil had low organic $\mathrm{C}$ and nutrient content, including total $\mathrm{N}, \mathrm{P}$, compared with both Al-WTR and compost. However, available $\mathrm{P}$ in the soil $\left(6 \mathrm{mg} \mathrm{kg}^{-1}\right)$ was slightly higher than in the Al-WTR ( $5 \mathrm{mg} \mathrm{kg}^{-1}$ ) (Table 2). The low levels of cations in the soil were also consistent with a low CEC. The compost used in the study had a high nutrient content in general and a very high CEC, but low $\mathrm{pH}$ and a high C:N (Table 2). The Al-WTR, on the other hand, had a moderate $\mathrm{pH}(\mathrm{pH}$ 5.7), which is favourable for maize production. The Al-WTR also had total $\mathrm{N}$, which was equivalent to compost averaging $1.28 \%$.

Effects of different treatments on maize growth and biomass partitioning

A slow growth response of plant height to all treatments was observed until day 14; thereafter, a sudden increase in plant height was observed for compost treatments, the co-amendment and standard NPK (Fig. 1a). At 35 days after planting, the maize plant height was $60.17 \pm 1.2 \mathrm{~cm}$ for the co-amendment, $10 \%$ Al-WTR $+10 \% \mathrm{C}+\mathrm{P}$, which was 


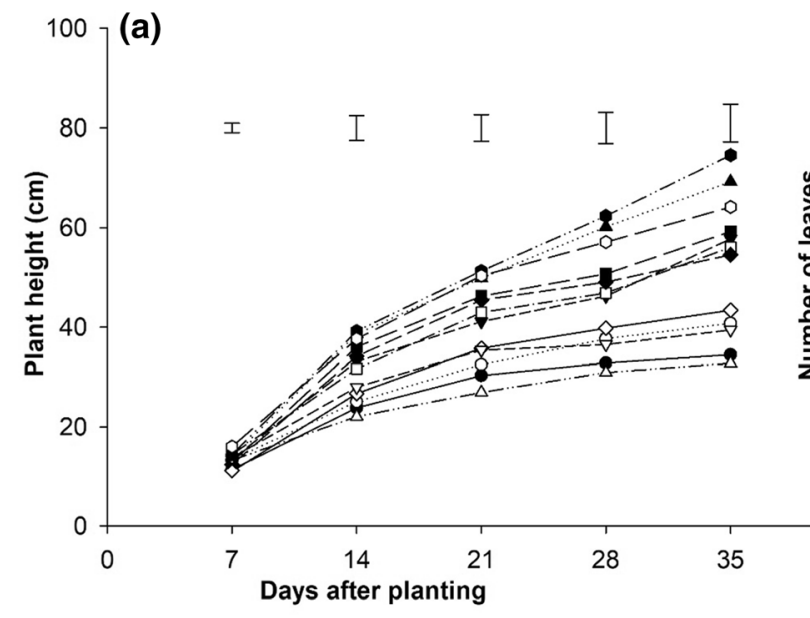

Fig. 1 Effects of different soil amendments on maize plant height (a) and mean number of leaves (b), C-compost; C + Pcompost + inorganic basal P; Al-WTR-aluminium water treatment residual; Al-WTR $+\mathrm{P}$-aluminium water treatment

significantly higher than $40.83 \pm 3.5 \mathrm{~cm}$ and $54.58 \pm 1.6 \mathrm{~cm}$ observed for the unamended control and standard NPK, respectively. Maize plant height for $10 \% \mathrm{Al}-\mathrm{WTR}+10 \% \mathrm{C}+\mathrm{P}, \quad 10 \% \mathrm{C}+\mathrm{P}$ $(69 \pm 1.8 \mathrm{~cm})$ and $20 \% \mathrm{C}+\mathrm{P}(70 \pm 1.8 \mathrm{~cm})$ was comparable (Fig. 1a). Number of leaves also followed a similar trend to plant height in both instances (Fig. 1b). Both the plant height and leaf number decreased with an increased concentration of Al-WTR from 10 to $20 \%$ (Fig. 1). Except in Al-WTR treatments, the addition of $\mathrm{P}$ fertilizer resulted in significant increase in plant height for all treatments. The addition of $P$ fertilizer had no influence in number of leaves except that they were only smaller in size in treatments without $\mathrm{P}$ (Fig. 1b).

Maize above-ground (shoot) dry matter accumulation was highest $(10.67 \pm 0.55 \mathrm{~g})$ in the $20 \% \mathrm{C}+\mathrm{P}$ treatment, whilst the least $(0.76 \pm 0.07 \mathrm{~g})$ was observed for the $20 \%$ WTR (Fig. 2a). The co-amendment, $10 \%$ Al-WTR $+10 \% \quad \mathrm{C}$ significantly (b)
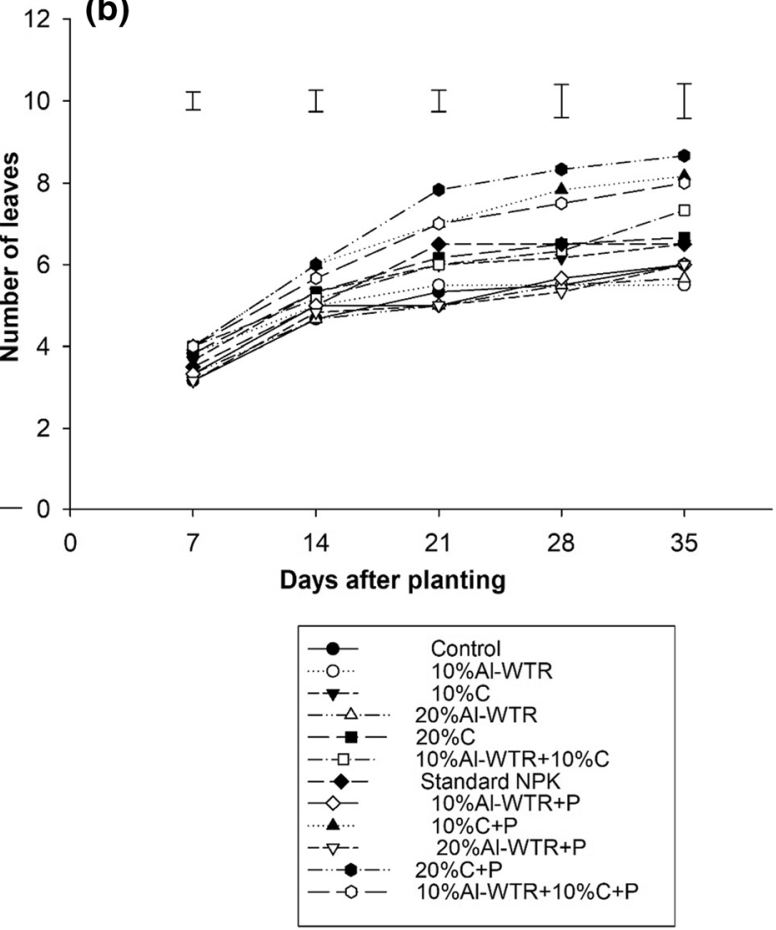

residual + inorganic basal P; Std NPK-standard inorganic fertilizer consisting of compound D and ammonium nitrate. Error bars denote standard errors of the differences between means $(\mathrm{SED})(n=6)$

$(\mathrm{p}<0.05)$ yielded $3.92 \pm 0.16 \mathrm{~g}$ higher shoot biomass than the unamended control which produced $1.33 \pm 0.17 \mathrm{~g}$. The addition of $\mathrm{P}$ fertilizer to the coamendment $(10 \% \quad$ Al-WTR $+10 \% \quad$ C) further increased maize dry matter yield about twofold $(7.23 \pm 0.07 \mathrm{~g})$ (Fig. 2a). There was, however, no significant difference in maize shoot dry matter biomass between $10 \% \quad \mathrm{Al}-\mathrm{WTR}+10 \% \quad \mathrm{C}+\mathrm{P}$ $(7.23 \pm 0.07 \mathrm{~g})$ and $10 \% \mathrm{C}+\mathrm{P}$, which yielded $7.5 \mathrm{~g} \pm 0.10 \mathrm{~g}$ (Fig. 2a). The co-amendment of $10 \%$ Al-WTR $+10 \% \quad \mathrm{C}$ also yielded significantly $(p<0.05)$ higher shoot biomass compared with $10 \%$ $\mathrm{C}$ and standard NPK. Except for sole Al-WTR treatments, the addition of $\mathrm{P}$ fertilizer significantly $(p<0.05)$ increased shoot biomass yield across all treatments (Fig. 2a).

The highest root dry matter accumulation was attained in the treatment $20 \% \mathrm{C}+\mathrm{P}$ with $2.57 \pm 0.22 \mathrm{~g}$, but this did not differ significantly with $10 \%$ WTR $+10 \% \mathrm{C}+\mathrm{P}$ with $2.4 \pm 0.07 \mathrm{~g}$ and 

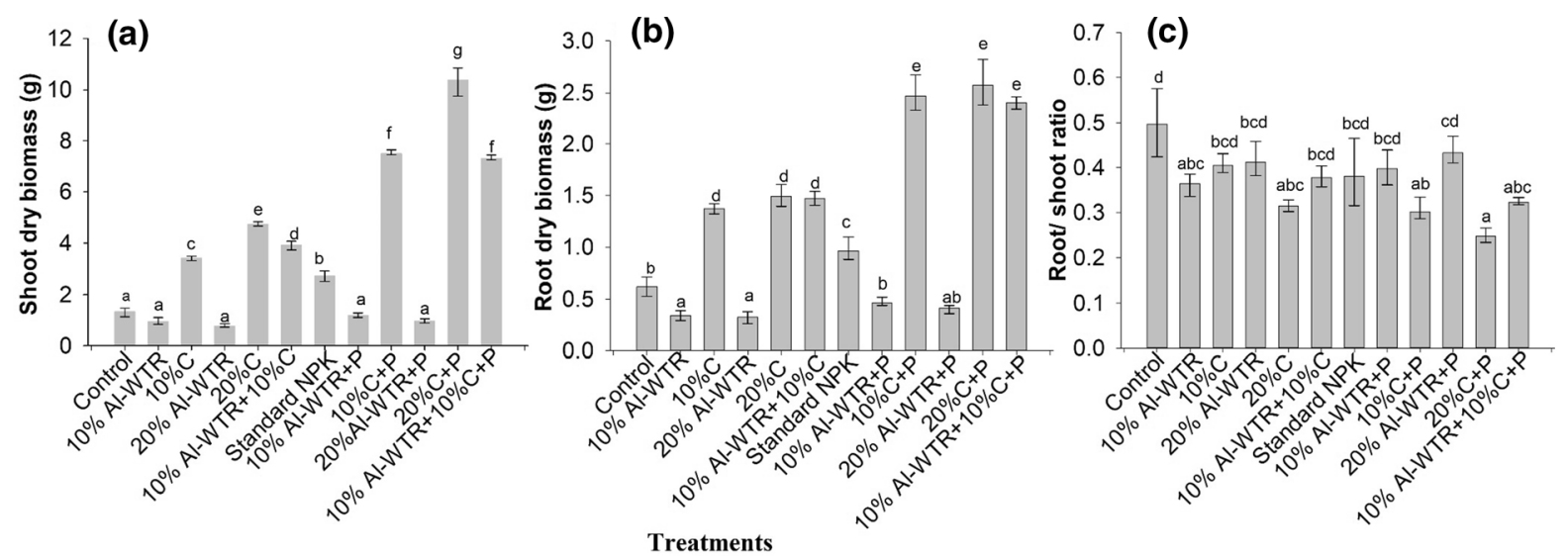

Fig. 2 Shoot (a) and root (b) dry matter accumulation and root/shoot ratios (c) for different soil amendments at 5 weeks after emergence. Bars represent mean $\pm \mathrm{SE}(n=6)$. Bars with different letters are significantly different at $p<0.05$

$10 \% \mathrm{C}+\mathrm{P}$ with $2.45 \pm 0.17 \mathrm{~g}$ (Fig. 2b). Likewise, root dry matter in the $10 \% \mathrm{C}, 20 \% \mathrm{C}$ and $10 \% \mathrm{Al}-$ $\mathrm{WTR}+10 \% \mathrm{C}$ treatments did not differ statistically. Contrary to shoot biomass, the control yielded higher root biomass at $0.62 \pm 0.09 \mathrm{~g}$ compared with $10 \%$ and 20\% Al-WTR treatments both yielded $<0.35 \mathrm{~g}$ (Fig. 2b). Consistent with shoot biomass, both $10 \%$ $\mathrm{Al}-\mathrm{WTR}+10 \% \mathrm{C}+\mathrm{P}$ and $10 \% \mathrm{Al}-\mathrm{WTR}+10 \% \mathrm{C}$ yielded significantly $(p<0.05)$ higher root biomass relative to standard NPK (Fig. 2b). The addition of $\mathrm{P}$ fertilizer significantly increased root biomass yield across all treatments.

The control had the highest root-to-shoot ratio with $0.5 \pm 0.02$, whilst $20 \% \mathrm{C}+\mathrm{P}$ had the least at $0.25 \pm 0.01$ with the rest coming in between (Fig. 2c). Root-to-shoot ratios were generally low in both $10 \%$ $\mathrm{Al}-\mathrm{WTR}+10 \% \mathrm{C}+\mathrm{P}$ and $10 \% \mathrm{Al}-\mathrm{WTR}+10 \% \mathrm{C}$ compared with sole Al-WTR and the control (Fig. 2c). However, similar root/shoot ratios were observed in $10 \% \mathrm{Al}-\mathrm{WTR}+10 \% \mathrm{C}+\mathrm{P}$, and $10 \% \mathrm{C}+\mathrm{P}$ (Fig. 2c). Overall, these data revealed that the coamendment resulted in higher maize growth (plant height, number of leaves and dry matter accumulation) relative to the unamended control, standard NPK and sole Al-WTR treatments.

Uptake of nitrogen $(\mathrm{N})$ and phosphorus

(P) by maize

Except for $20 \% \mathrm{C}+\mathrm{P}$ with $39.38 \pm 0.01 \mathrm{~g} \mathrm{~N} \mathrm{~kg}^{-1}$, $\mathrm{N}$ uptake for the co-amendment $10 \%$ Al-WTR $+10 \%$
$\mathrm{C}+\mathrm{P}$ of $31.86 \pm 0.01 \mathrm{~g} \mathrm{~N} \mathrm{~kg}^{-1}$ was significantly $(p<0.05)$ higher than for the rest of the treatments (Fig. 3a). The least $\mathrm{N}$ uptake was observed in the unamended control with $1.43 \pm 0.01 \mathrm{~g} \mathrm{~N} \mathrm{~kg}^{-1}$ (Fig. 3a). Nitrogen uptake in the control, however, did not differ for both 10 and 20\% Al-WTR treatments. Addition of $\mathrm{P}$ fertilizer had a significant influence on $\mathrm{N}$ uptake by maize across all treatments except for the sole Al-WTR treatments. Only the treatment $20 \% \mathrm{C}+\mathrm{P}$ exceeded the critical $\mathrm{N}$ limit in maize plant tissue (Fig. 3a).

There was a contrasting trend in $\mathrm{P}$ uptake relative to $\mathrm{N}$ uptake. Uptake of $\mathrm{P}$ for both co-amendments of $10 \%$ Al-WTR $+10 \% \mathrm{C}+\mathrm{P}\left(1.08 \pm 0.08 \mathrm{~g} \mathrm{P} \mathrm{kg}^{-1}\right)$ and $10 \% \mathrm{Al}-\mathrm{WTR}+10 \% \mathrm{C}\left(0.43 \pm 0.06 \mathrm{~g} \mathrm{P} \mathrm{kg}^{-1}\right)$ was significantly $(p<0.05)$ higher than for the unamended control with $0.11 \pm 0.04 \mathrm{~g} \mathrm{P} \mathrm{kg}^{-1}$ (Fig. 3b). However, both 10 and $20 \%$ compost treatments $( \pm P)$ resulted in significantly higher $\mathrm{P}$ uptake compared with $10 \%$ Al-WTR $+10 \% \mathrm{C}$ and $10 \%$ Al-WTR + $10 \% \mathrm{C}+\mathrm{P}$ (Fig. 3b). Consistent with $\mathrm{N}$ uptake, $10 \%$ Al-WTR $+10 \% \mathrm{C}+\mathrm{P}$ had significantly higher $\mathrm{P}$ uptake compared with standard NPK, which attained $0.67 \pm 0.07 \mathrm{~g} \mathrm{P} \mathrm{kg}^{-1}$. Although not significantly different, the uptake of $\mathrm{P}$ declined with increase from 10 to $20 \%$ Al-WTR levels. The addition of P fertilizer did not result in significant changes in P uptake in AlWTR treatments (Fig. 3b). Phosphorus uptake across all treatments fell below the critical limit for $\mathrm{P}$ $\left(3 \mathrm{~g} \mathrm{~kg}^{-1}\right)$ (Fig. 3b). 


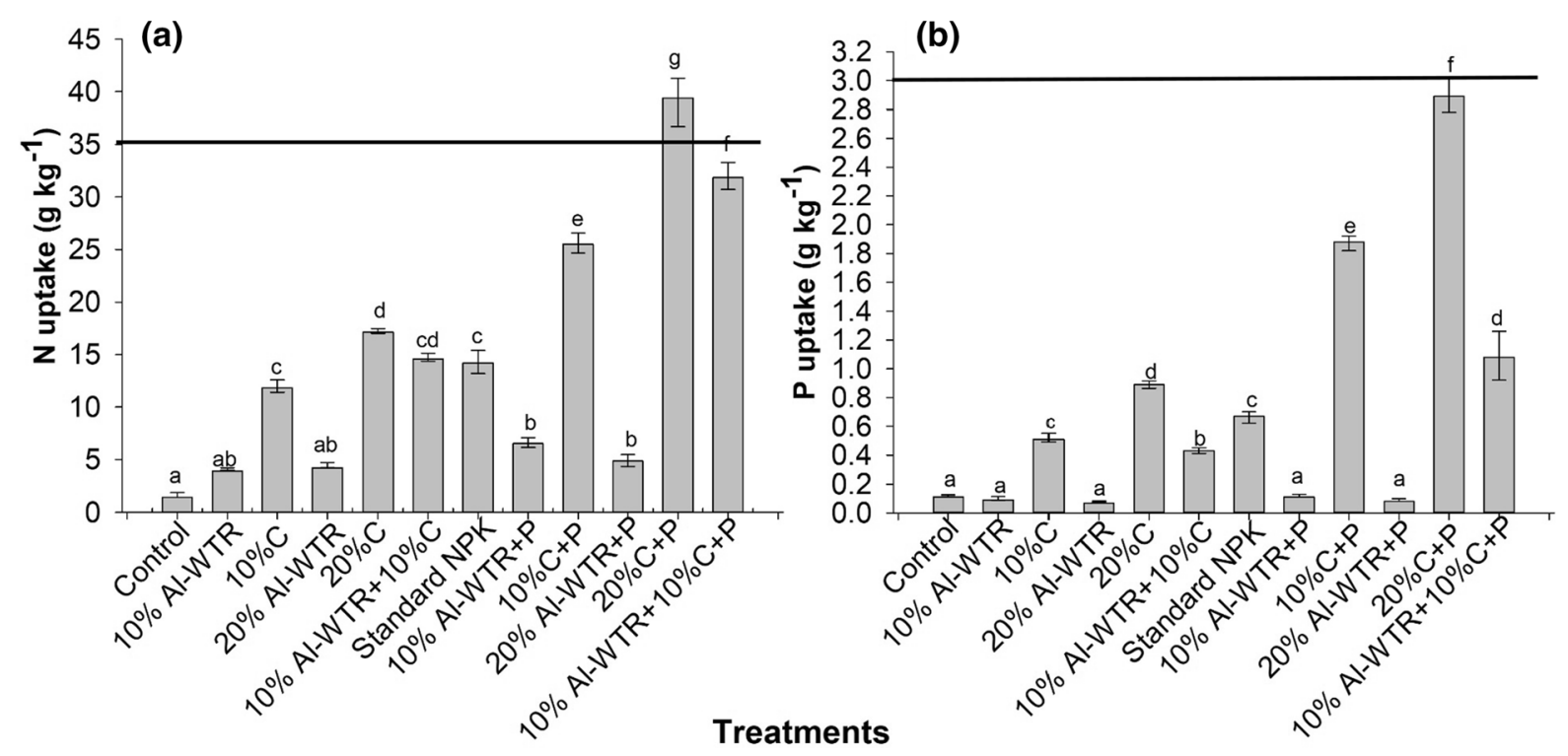

Fig. 3 Total N (a) and P (b) uptake by maize for different soil amendments at 5 weeks after emergence. The solid horizontal lines represent the critical $\mathrm{N}$ and $\mathrm{P}$ levels in maize tissue

Generally, results revealed that the addition of $\mathrm{P}$ fertilizer resulted in improved uptake of $\mathrm{N}$ and $\mathrm{P}$ by maize across all treatments except for sole Al-WTR treatments. P uptake was lower across all treatments in comparison with $\mathrm{N}$ (Fig. 3).

Effects of different soil amendments on soil chemical properties at harvest

Post-harvest soil $\mathrm{pH}$ due to sole Al-WTR treatments and both the 10\%Al-WTR $+10 \% \mathrm{C}$ and $10 \% \mathrm{Al}-\mathrm{WTR}$ $+10 \% \mathrm{C}+\mathrm{P}$ was comparable, whilst all compost treatments had a significantly lower $\mathrm{pH}$ (Table 3 ). This is possibly because the compost used in the experiment had very low $\mathrm{pH}$ (see Table 2). Electrical conductivity (EC) in 10\%Al-WTR + 10\%C + P (1.79 $\pm 0.07)$ was comparable to $20 \% \mathrm{C}(1.84 \pm 0.07)$ and significantly $(\mathrm{p}<0.05)$ higher relative to the unamended control, sole WTR and standard NPK (Table 3). Although compost treatments had a significantly higher CEC compared to the rest of the treatments, both $10 \% \mathrm{Al}-\mathrm{WTR}+10 \% \mathrm{C}$ and $10 \% \mathrm{Al}-$ $\mathrm{WTR}+10 \% \mathrm{C}+\mathrm{P}$, in turn had significantly higher CEC in comparison with the unamended control, standard NPK and sole WTR treatments. 10\% Al$\mathrm{WTR}+10 \% \mathrm{C}+\mathrm{P}$ had the highest $\mathrm{P}$ content $(0.083 \%$
(Tandon, 1993). Bars are mean \pm se $(n=3)$. Means with the same letter do not differ significantly at $p<0.05$

$\pm 1.1)$ whilst the control $(0.04 \% \pm 0.03)$ had the lowermost (Table 3).

Even though, residual soil basic cations $(\mathrm{Ca}$ and $\mathrm{Mg}$ ) were generally higher in compost treatments, both $10 \%$ Al- WTR $+10 \% \mathrm{C}$ and $10 \%$ Al-WTR + $10 \% \mathrm{C}+\mathrm{P}$ had significantly $(\mathrm{p}<0.05)$ higher $\mathrm{Ca}$ and $\mathrm{Mg}$ than the control (Table 3). Contrastingly, soil residual $\mathrm{K}$ was significantly higher in soil only treatments - the control and standard NPK as compared to the rest of the other treatments. There were also significantly $(\mathrm{P}<0.05)$ higher levels of residual $\mathrm{Zn}, \mathrm{Cu}$ and $\mathrm{Mn}$ in sole Al-WTR treatments compared to the rest of the other treatments (Table 3). Residual $\mathrm{Pb}$ and $\mathrm{Ni}$ were comparable among $10 \% \mathrm{Al}-\mathrm{WTR}+$ $10 \% \mathrm{C}+\mathrm{P}, \mathrm{Al}-\mathrm{WTR}$ treatments and standard NPK. $20 \%$ Al-WTR $+\mathrm{P}$ had significantly $(\mathrm{P}<0.05)$ higher Al levels as compared to the rest of the treatments. However, the post-harvest metal levels were lower than the maximum limits for the metals in agricultural soils (see table 1).

Uptake of basic cations by maize

Except for the treatment $20 \% \mathrm{C}+\mathrm{P}(4.35 \pm 0.17 \mathrm{~g}$ $\mathrm{Ca} \mathrm{kg}^{-1}$ ), the co-amendment of $10 \% \mathrm{Al}-\mathrm{WTR}+10 \%$ $\mathrm{C}+\mathrm{P}\left(3.88 \pm 0.23 \mathrm{~g} \mathrm{Ca} \mathrm{kg}^{-1}\right)$ resulted in higher $\mathrm{Ca}$ 

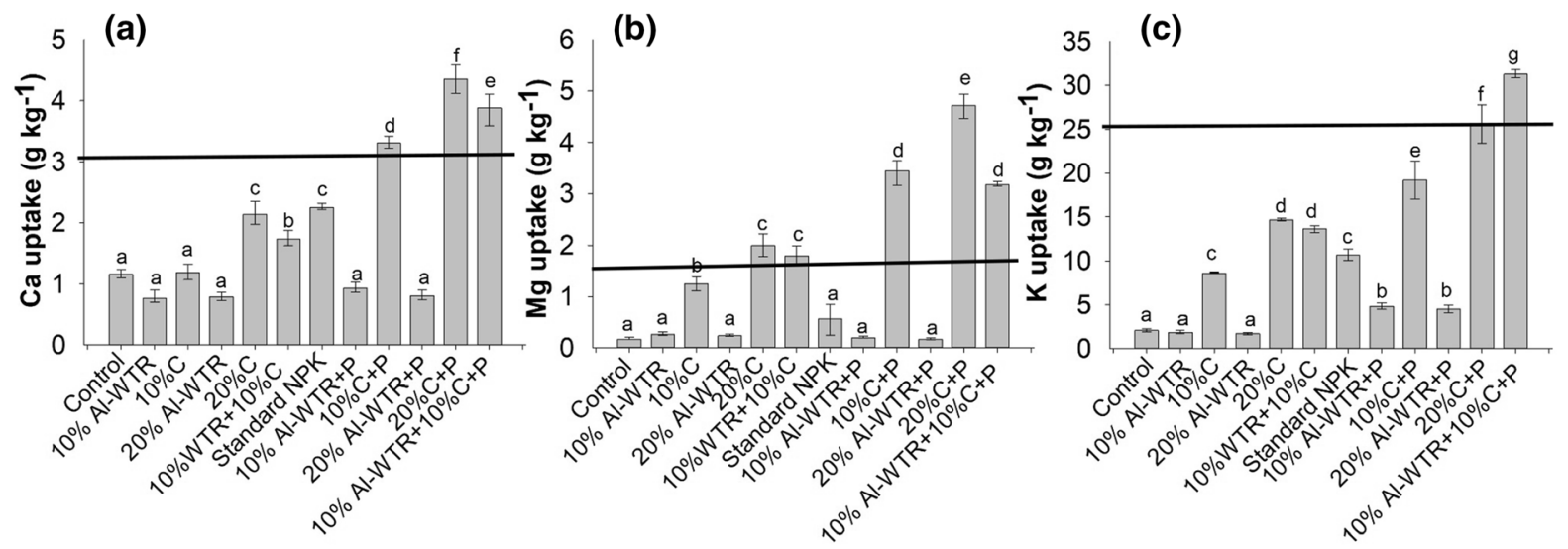

Treatments

Fig. 4 Mean values of $\mathrm{Ca}(\mathbf{a}), \mathrm{Mg}(\mathbf{b})$ and $\mathrm{K}$ (c) uptake by maize at 35 days after emergence. The solid horizontal lines represent critical limits for $\mathrm{Ca}, \mathrm{Mg}$ and $\mathrm{K}$ in maize plant tissue (Tandon

uptake by maize compared with the rest of the treatments (Fig. 4a). The lowest uptake was in $20 \%$ Al-WTR with $0.79 \pm 0.58 \mathrm{~g} \mathrm{Ca} \mathrm{kg}^{-1}$. The addition of $\mathrm{P}$ fertilizer resulted in an increase in the uptake of $\mathrm{Ca}$ across all treatments except sole Al-WTR treatments (Fig. 4a). The co-amendment, 10\% Al-WTR $+10 \%$ $\mathrm{C}+\mathrm{P} ; 10 \% \mathrm{C}+\mathrm{P}$ and $20 \% \mathrm{C}+\mathrm{P}$ attained more than $3 \mathrm{~g} \mathrm{Ca} \mathrm{kg}^{-1}$; a value which is above the critical $\mathrm{Ca}$ level required in maize plant tissue.

Uptake of $\mathrm{Mg}$ followed a similar trend to $\mathrm{Ca}$, with $20 \% \mathrm{C}+\mathrm{P}$ consistently attaining the highest uptake. The co-amendment, $10 \%$ Al-WTR $+10 \% \mathrm{C}+\mathrm{P}$ in turn attained a higher $\mathrm{Mg}$ uptake than the control $\left(0.17 \pm 0.01 \mathrm{~g} \mathrm{Mg} \mathrm{kg}^{-1}\right)$ and standard NPK (Fig. 4b). Similarities in the uptake of $\mathrm{Mg}$ were observed for $10 \% \mathrm{Al}-\mathrm{WTR}+10 \% \mathrm{C}+\mathrm{P}$ and $10 \%$ $\mathrm{C}+\mathrm{P} ; 10 \% \mathrm{Al}-\mathrm{WTR}+10 \% \mathrm{C}$ and $10 \% \mathrm{C}$ and for standard NPK, the control and Al-WTR treatments (Fig. 4b). Except for the Al-WTR treatments, the addition of $\mathrm{P}$ fertilizer increased the uptake of $\mathrm{Mg}$ across all treatments. Overall, the co-amendment $(10 \% \mathrm{Al}-\mathrm{WTR}+10 \% \mathrm{C}$ and $10 \% \mathrm{Al}-\mathrm{WTR}+10 \%$ $\mathrm{C}+\mathrm{P})$, and the compost treatments $( \pm \mathrm{P})$ exceeded $1.5 \mathrm{~g} \mathrm{Mg} \mathrm{kg}^{-1}$, the critical $\mathrm{Mg}$ level in maize plant tissue.

Contrasting to $\mathrm{Ca}$ and $\mathrm{Mg}$ uptake, the highest $\mathrm{K}$ uptake was observed for the co-amendment, $10 \% \mathrm{Al}-$ $\mathrm{WTR}+10 \% \quad \mathrm{C}+\mathrm{P}$, which attained $31.25 \pm 0.29 \mathrm{~g} \mathrm{~K} \mathrm{~kg}^{-1}$, while the lowest was recorded for $20 \%$ Al-WTR with
1993). Bars are mean $\pm \mathrm{SE}(n=3)$. Means that do not differ significantly at $p<0.05$ contain the same letter

$1.72 \pm 0.21 \mathrm{~g} \mathrm{~K} \mathrm{~kg}^{-1}$ (Fig. 4c). Both co-amendments, $10 \%$ Al-WTR $+10 \% \mathrm{C}$ and $10 \% \mathrm{Al}-\mathrm{WTR}+$ $10 \% \mathrm{C}+\mathrm{P}$, resulted in significantly $(p<0.05)$ higher $\mathrm{K}$ uptake relative to the control and standard NPK. Uptake of K was comparable for $10 \% \mathrm{C}$ and $10 \%$ Al-WTR $+10 \% \mathrm{C}$. Addition of P fertilizer had a positive influence in $\mathrm{K}$ uptake across all the treatments. The co-amendment, $10 \%$ Al-WTR $+10 \%$ $\mathrm{C}+\mathrm{P}$, was the only treatment that exceeded $25 \mathrm{~g} \mathrm{~K} \mathrm{~kg}^{-1}$, the critical limit of $\mathrm{K}$ in maize plant tissue. Uptake of $\mathrm{K}$ by maize was generally higher than $\mathrm{Ca}$ and $\mathrm{Mg}$ uptake (Fig. 4).

Micronutrients uptake by maize

The highest $\mathrm{Zn}$ uptake by maize, $20.19 \pm 0.02 \mathrm{mg} \mathrm{Zn}$ $\mathrm{kg}^{-1}$, was observed for the co-amendment, $10 \% \mathrm{Al}-$ WTR $+10 \% \mathrm{C}+\mathrm{P}$, whilst the lowest was observed for the unamended control with $0.86 \pm 0.1 \mathrm{mg} \mathrm{Zn}$ $\mathrm{kg}^{-1}$ (Fig. 5a). High $\mathrm{Zn}$ uptake by maize was also observed for the co-amendment (Fig. 5a). Uptake of $\mathrm{Cu}$ followed a similar trend to $\mathrm{Zn}$, with the highest amounts observed for $10 \%$ Al-WTR $+10 \% \mathrm{C}+\mathrm{P}$ $\left(2.95 \pm 0.15 \mathrm{mg} \mathrm{Cu} \mathrm{kg}^{-1}\right)$. The control had the lowest uptake of $0.32 \pm 0.03 \mathrm{mg} \mathrm{Cu} \mathrm{kg}^{-1}$ (Fig. 5b). Except for the sole Al-WTR treatments, the addition of $\mathrm{P}$ fertilizer generally increased $\mathrm{Zn}$ and $\mathrm{Cu}$ uptake across the treatments.

$\mathrm{Pb}$ uptake was largest in compost treatments with the highest value of $0.26 \pm 0.01 \mathrm{mg} \mathrm{Pb} \mathrm{kg}^{-1}$ observed 

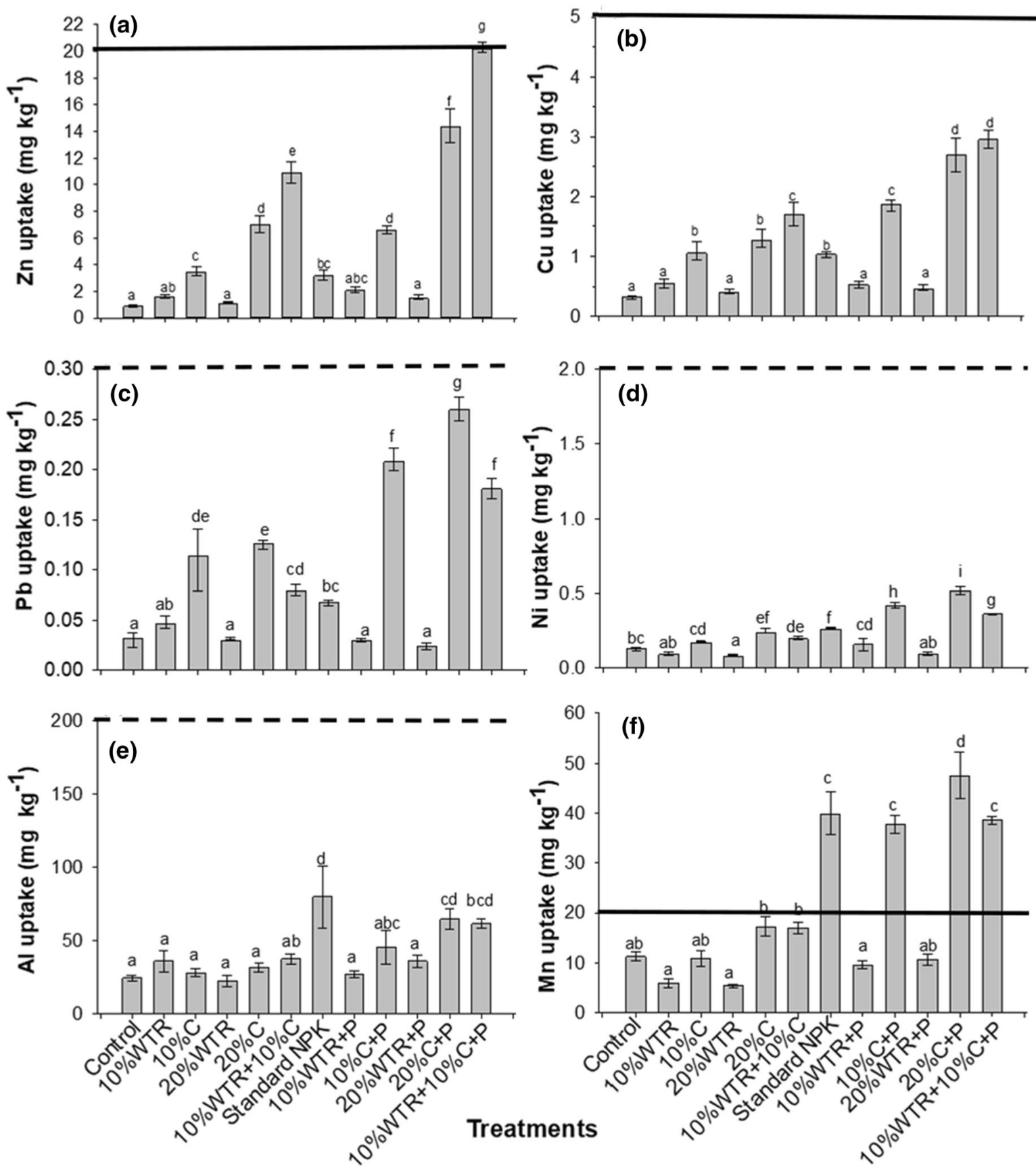

Fig. 5 Average values of $\mathrm{Zn} \mathrm{(a)} \mathrm{and} \mathrm{Cu}(\mathbf{b}), \mathrm{Pb}(\mathbf{c})$ and $\mathrm{Ni}(\mathbf{d})$, and $\mathrm{Al}$ (e) and $\mathrm{Mn}$ (f) uptake by maize at 5 weeks after emergence. The solid horizontal lines represent critical limits for $\mathrm{Zn}, \mathrm{Cu}$ and $\mathrm{Mn}$ (Tandon 1993), while the broken lines

for $20 \% \mathrm{C}+\mathrm{P}$. There were no observed differences in $\mathrm{Pb}$ uptake between 10\% Al-WTR $+10 \% \mathrm{C}$ and standard NPK (Fig. 5c). Compared with compost represent toxicity thresholds for $\mathrm{Pb}$ (FAO/WHO 2001), Ni (WHO 1996) and Al (Pais and Jones Jr 1997). Bars are mean $\pm \mathrm{SE}(n=3)$. Means that do not differ significantly at $p<0.05$ contain the same letter

treatments, $10 \% \mathrm{Al}-\mathrm{WTR}+10 \% \mathrm{C}+\mathrm{P}$ resulted in reduced uptake of $\mathrm{Pb}$ (Fig. 5c). Consistent with $\mathrm{Pb}$ uptake, uptake of Ni followed a similar trend with $20 \%$ 


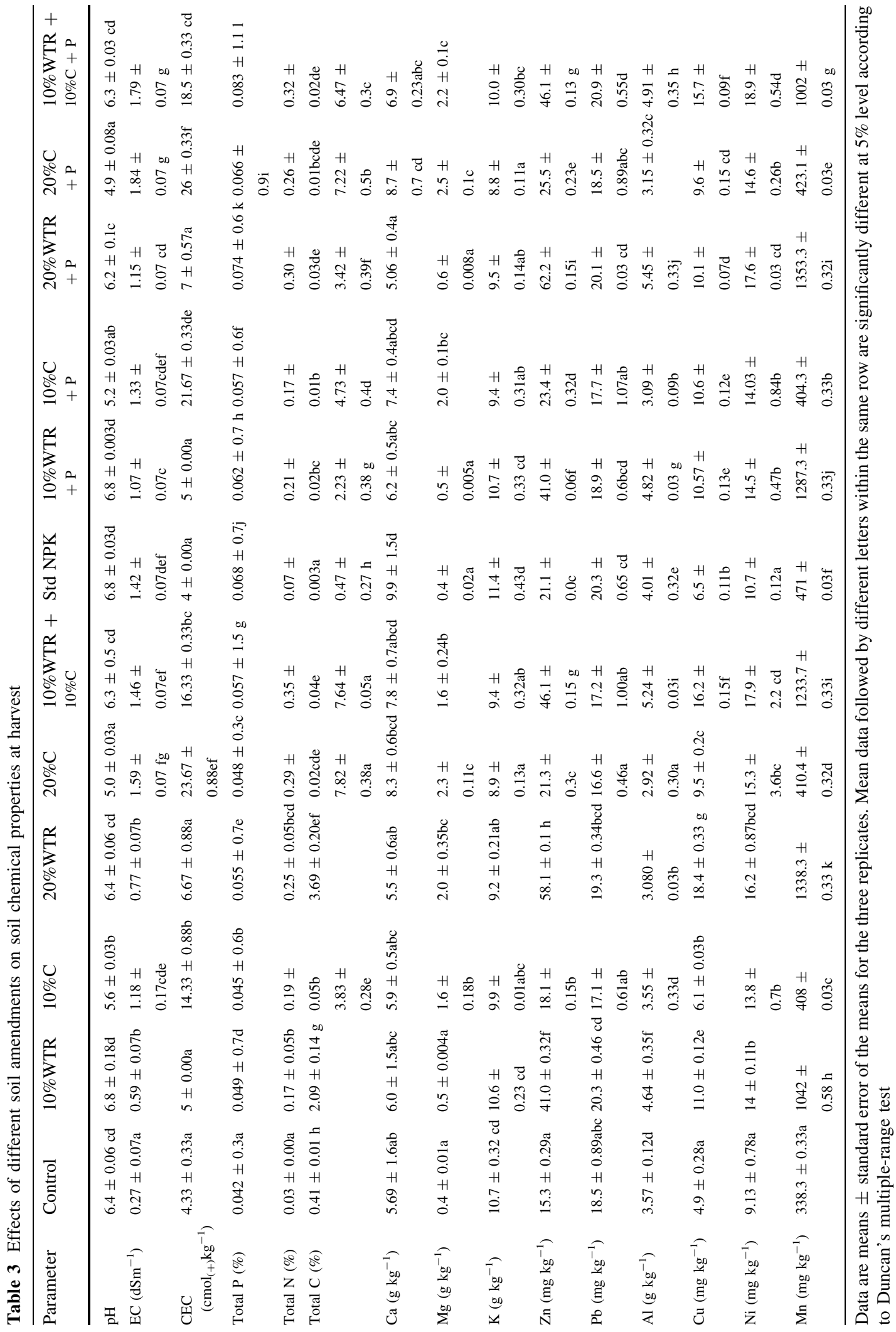


$\mathrm{C}+\mathrm{P}$ yielding the highest uptake of $0.52 \pm 0.02 \mathrm{mg}$ $\mathrm{Ni} \mathrm{kg}{ }^{-1}$, whilst $20 \%$ Al-WTR had the least with $0.09 \pm 0.01 \mathrm{mg} \mathrm{Ni} \mathrm{kg}{ }^{-1}$ (Fig. 5d) The co-amendment, $10 \% \mathrm{Al}-\mathrm{WTR}+10 \% \mathrm{C}+\mathrm{P}$, resulted in lower uptake of $\mathrm{Ni}$ by maize compared with $10 \% \mathrm{C}+\mathrm{P}$. Except for Al-WTR treatments, the addition of $\mathrm{P}$ fertilizer resulted in an increase in $\mathrm{Pb}$ uptake in all treatments, whilst there were no significant effects on uptake of Ni across all treatments. All treatments were below the toxicity threshold levels for both $\mathrm{Pb}$ and $\mathrm{Ni}$ (Fig. 5c, d).

The highest uptake of $\mathrm{Al}(79.95 \pm 21.2 \mathrm{mg} \mathrm{Al}$ $\mathrm{kg}^{-}$1) was observed for standard NPK, while the lowest $\left(22.6 \pm 3.7 \mathrm{mg} \mathrm{Al} \mathrm{kg}{ }^{-1}\right)$ was observed for $20 \%$ Al-WTR (Fig. 5e). The Al uptake by maize observed for all treatments was below the toxicity threshold level of $\mathrm{Al}\left(200 \mathrm{mg} \mathrm{kg}^{-1}\right)$. Uptake of $\mathrm{Mn}$ was highest $\left(47.5 \pm 4.6 \mathrm{mg} \mathrm{Mn} \mathrm{kg}{ }^{-1}\right)$ in the $20 \%$ $\mathrm{C}+\mathrm{P}$ and lowest $\left(5.34 \pm 0.32 \mathrm{mg} \mathrm{Mn} \mathrm{kg}^{-1}\right)$ in the 20\% Al-WTR. The co-amendment, 10\% Al-WTR + $10 \% \mathrm{C}+\mathrm{P}$, resulted in higher Mn uptake compared with the unamended control (Fig. 5f).

Overall, the co-amendment $10 \%$ Al-WTR $+10 \%$ $\mathrm{C}+\mathrm{P}$ resulted in lower uptake of $\mathrm{Ni}$ and $\mathrm{Pb}$ relative to sole compost treatments, whilst there were no significant differences in uptake of Al. Additionally, 10\% $\mathrm{Al}-\mathrm{WTR}+10 \% \mathrm{C}+\mathrm{P}$ resulted in an increase in $\mathrm{Zn}$ and $\mathrm{Cu}$ uptake relative to all other treatments including the control (Fig. 5).

\section{Discussion}

Characteristics of soil and amendment materials

The soil used in this study had high sand content (73\%) and very low $\mathrm{pH}$ (4.0), which is considered very strongly acidic for Zimbabwean soils (Nyamangara \& Mpofu, 1996). The high sand content means it has low nutrient retention capacity. The $\mathrm{pH}$ of 5.7 observed for Al-WTR is favourable for maize production, whilst that of compost, $\mathrm{pH} 4.8$ is considered acidic and too low for maize growth. Soil $\mathrm{pH}$ has an impact on nutrient availability as it can render some essential plant nutrients unavailable for plant uptake whilst making others toxic for plant growth. Thus, the AlWTR can play a critical role as a liming material, given that most of the soils in Zimbabwe as in many other countries in SSA are acidic. The Al-WTR's relatively higher CEC than the control means that it has a relatively higher capacity to retain and supply plant nutrients compared with the soil. Total P of AlWTR was higher than the soil and compost, but its available $P$ was less than both, implying that most of the $\mathrm{P}$ in the Al-WTR was not readily available for plant uptake due perhaps to adsorption by the $\mathrm{Al}$ oxides in the WTR. Metal concentration of the AlWTR was also higher than the control and compost but well below the European maximum permissible levels for heavy metals (Tóth et al., 2016). The Al-WTR is thus safe for land application as far as metal levels are concerned. The relatively high CEC in the compost proffers an advantage in nutrient retention capacity.

The similarity in post-harvest soil $\mathrm{pH}$ between the co-amendments $(10 \%$ Al-WTR $+10 \% \mathrm{C}+\mathrm{P}$ and $10 \% \mathrm{Al}-\mathrm{WTR}+10 \% \mathrm{C}$ ) and sole Al-WTR treatments is suggestive of the potential of WTR to modify soil pH (Hastings \& Dawson, 2012). Al-WTR was able to mask the low $\mathrm{pH}$ due to compost in the co-amendment. The CEC of the residual soil due to the co-amendment was also higher than that for sole Al-WTR amended soils, and this was consistent with findings by Hsu \& Hseu, 2011. This was attributed to the compost component in the co-amendment, which had a high CEC. From these results, it is evident that the benefits of combining Al-WTR and compost outweigh the benefits of sole use of these nutrient resources. The resultant lower concentrations of $\mathrm{Zn}, \mathrm{Pb}, \mathrm{Al}$ and $\mathrm{Cd}$ in both $10 \%$ Al-WTR $+10 \% \mathrm{C}+\mathrm{P}$ and $10 \% \mathrm{Al}-$ $\mathrm{WTR}+10 \% \mathrm{C}$ in comparison with sole Al-WTR could be attributed to the presence of organic matter from the compost. Heavy metals become sorbed on the active sites on organic matter surfaces and form stable complexes with humic substances (Clemente \& Bernal, 2006), making them less bioavailable. Even though metal levels for $10 \%$ Al-WTR $+10 \% \mathrm{C}+\mathrm{P}$ were elevated relative to the control and standard NPK, they were not bioavailable (Hovsepyan \& Bonzongo, 2009). We attributed this to the favourable $\mathrm{pH}$ conditions proffered due to Al-WTR. Most metals including $\mathrm{Al}$ are bioavailable in acidic soils with a $\mathrm{pH}<5.5$. Al toxicity inhibits root growth. The significantly higher amounts of $\mathrm{Ni}, \mathrm{Al}$ and $\mathrm{Mn}$ following the application of standard NPK mineral fertilizer could be linked to industrial processes during fertilizer manufacturing, which may have resulted in heavy metal contamination of the fertilizer. In the absence of organic matter, the metals become 
bioavailable. However, total metal levels in all the treatments were low in comparison with the European Community maximum limits. The high $\mathrm{K}$ in the control soil could be attributed to the granitic nature of the soil, which is inherently high in K (Nyamapfene, 1991).

\section{Impact of Al-WTR use in maize production}

The observed decrease in plant growth and dry matter yield with the increase in concentration of Al-WTR suggests that Al-WTR amendment levels greater than $10 \%$ could be detrimental to plant growth. This is consistent with findings by Rengasamy et al. (1980) and Mahdy et al. (2007) where growth of maize in WTR amended soils increased until threshold application levels of $10 \mathrm{~g} / \mathrm{kg}$ and $30 \mathrm{~g} / \mathrm{kg}$, respectively. However, compared to the control, the co-amendment of $10 \%$ Al-WTR, $10 \% \mathrm{C}$ and P fertilizer resulted in higher maize growth and total biomass accumulation. This is in agreement with the work of Clarke et al. (2019), which also found higher wheat biomass yield due to combined use of compost and WTR as a soil amendment compared with unamended soil. Similarly, Hsu and Hseu (2011) reported that co-application of compost and Al-WTR resulted in higher dry matter accumulation of Bahia grass (Paspalum notatum), although in their case, the resultant yield was not significantly different to sole Al-WTR treatments. The enhanced growth and biomass noted could be attributed to the synergy in nutrient supply between compost and the Al-WTR. Although WTRs are typically low in P (Dassayanake et al. 2015), compost addition provided readily available $\mathrm{P}$ (due to its higher content of available $\mathrm{P}$ as shown in Table 1), whilst WTR provided $\mathrm{N}$ and a favourable $\mathrm{pH}$ for nutrient uptake. Land application of WTR for plant production is often constrained due to potential adsorption of $\mathrm{P}$ by the $\mathrm{Al}$ and $\mathrm{Fe}$ oxides normally present in WTR, making $\mathrm{P}$ unavailable for plant uptake (Babatunde et al., 2008; Bai et al., 2014; Norris \& Titshall, 2012). The similarity in maize dry matter yield between $10 \%$ $\mathrm{Al}-\mathrm{WTR}+10 \% \mathrm{C}+\mathrm{P}$ and $10 \% \mathrm{C}+\mathrm{P}$ suggests that WTR can be used as a co-amendment with compost to increase maize yields and could thus reduce production costs by using half of expensive composts as the WTR is freely available.

The increase in maize growth and biomass accumulation due to the addition of $\mathrm{P}$ fertilizer accentuates the notion that the addition of inorganic $\mathrm{P}$ may, thus, help to alleviate problems of $\mathrm{P}$ fixation that leads to $\mathrm{P}$ deficiency in WTR amended soils (Basta, 2000). For example, Heil and Barbarick (1989) reported increased yield of Sorghum bicolor (Moench) in WTR amended soils through additions of inorganic P, whilst Lucas et al. (1994) showed that P deficiency in Fescue (Festuca arundinaceae) caused by the application of $40 \mathrm{~g} \mathrm{~kg}^{-1}$ alum sludge could be corrected by doubling the recommended $\mathrm{P}$ fertilization rate. In this study, a fixed $P$ rate was used, which could have been too low to offset the negative P-fixing capacity of WTR. Further research may be needed to vary $\mathrm{P}$ rates and come up with optimal $\mathrm{P}$ application levels that can significantly offset the P-fixing capacity.

Poor plant growth and low biomass due to the unamended control attest that the soil used in the study is inherently infertile (Mapfumo \& Giller, 2001; Nyamangara et al., 2000; Nyamapfene, 1991), with additions of fertilizer, and compost consequently improved maize plant growth and total biomass accumulation. The observed poor maize growth and biomass accumulation for standard NPK application, which is the common soil fertility management practice in Zimbabwe, could be an indicator of soil degradation. Degraded soils are known to show a general weak response to mineral fertilizer additions (Nezomba et al., 2015). Soil degradation due to poor soil fertility management is a major constraint to crop productivity in many smallholder farming areas in SSA (Mapfumo \& Giller, 2001). Combining organic and inorganic nutrient resources has been proven to increase crop yields and nutrient efficiency in nutrientpoor soils (Mtambanengwe \& Mapfumo, 2006; Vanlauwe et al., 2010) with other potential benefits to the soil physical, chemical and biological properties (Nezomba et al., 2015; Zingore et al., 2015). Research has also shown that farmers fail to access organic nutrients in sufficient quantity and quality to maintain the critical soil $\mathrm{C}$ levels for sustainable soil productivity (Mapfumo \& Giller, 2001; Mtambanengwe \& Mapfumo, 2006). WTRs can potentially contribute to soil $\mathrm{C}$ build-up in the long term because the organic carbon becomes tightly bound in the $\mathrm{Fe}$ and $\mathrm{Al}$ oxide matrix (Elliott \& Dempsey, 1991; Novak \& Watts, 2004). Hence, co-application of WTR with other organic nutrient resources could be a complementary option to increase soil organic matter to sustain crop 
production and at the same time protect the environment.

The low root-to-shoot ratios observed in the coamendment compared to sole Al-WTR and the control signify better nutrient availability in the co-amendment. It is generally understood that when nutrients are available, plants allocate relatively less to the roots and more to the shoots and grain (Bonifas et al., 2005; Tilman, 1985) with exceptions where $\mathrm{Mg}$, K or Mn are limiting (Ericsson, 1995). However, in P-deficient soils, higher root-to-shoot ratios are common. The highest root-to-shoot ratio due to the control is evident of the poor soil nutrient status. Root-to-shoot ratio could thus be used as an indicator of nutrient resource use efficiency in crop production.

\section{Influence of Al-WTR amendment on plant nutrient uptake}

The inverse relation between soil and plant $\mathrm{P}$ due to the co-amendment of $10 \%$ Al-WTR $+10 \% \mathrm{C}+\mathrm{P}$ could suggest that some $\mathrm{P}$ could have been adsorbed and was thus unavailable for plant uptake. This could be attributed to the Al-WTR component of the coamendment. Phosphorus deficiency in crops normally occurs due to slow release of labile $\mathrm{P}$ into the soil solution. Several studies have demonstrated that in WTR amended soils, readily available $\mathrm{P}$ can be converted to forms inaccessible by plant roots (e.g. Babatunde et al., 2008; Bai et al., 2014). Higher P uptake due to additions of inorganic $\mathrm{P}$ fertilizer was expected as the $\mathrm{P}$ in the fertilizer is readily available for plant uptake. Adding P fertilizers to soils amended with Al-WTR has a potential to reduce $\mathrm{P}$ sorption by the WTR, rendering the latter available for plant uptake. Babatunde and Zhao (2010) in their investigation on the kinetics of P sorption of alum WTR (AlWTR) reported that initial sorption occurs on surface functional sites until these are saturated. This implies that added $\mathrm{P}$ fertilizer must satisfy these functional sites before it becomes available for plant uptake. However, this also implies additional P fertilizer cost on farmers. Cost-benefit analysis on long-term implications for WTR disposal into landfill vis-a-vis cost of $\mathrm{P}$ fertilizer will have to be done. Alternatively, $\mathrm{P}$ fertilizer subsidies can be made available to farmers willing to incorporate Al-WTR in their farms. The higher $\mathrm{N}$ uptake due to the co-amendment in comparison with Al-WTR treatments reinforces the mutual benefits in nutrient supply when Al-WTR and compost are used together (Clarke et al., 2019). The surge in $\mathrm{N}$ uptake observed in the co-amendment due to the addition of fertilizer $\mathrm{P}$ was likely a result of an increase in $\mathrm{P}$ availability and thus improved root development which enabled the plants to take up more $\mathrm{N}$ from the soil.

The high uptake of $\mathrm{Ca}, \mathrm{Mg}$ and $\mathrm{K}$ accruing to $10 \%$ $\mathrm{Al}-\mathrm{WTR}+10 \% \mathrm{C}+\mathrm{P}$ relative to the control, sole WTR and compost treatments was also ascribed to the mutual relation in nutrient supply between the AlWTR and compost, which had high levels of bases in addition to those from the WTR. The potential of WTR to supply cationic nutrients for plant growth and development has also been documented in the past (American Society of Civil Engineers et al. 1996; Dayton \& Basta, 2001). More so, the high CEC of the WTR attests to its potential to hold and supply cations. The trend in uptake of the cationic bases also showed that maize has a higher demand for K compared with $\mathrm{Ca}$ and $\mathrm{Mg}$. Potassium is required throughout the growth cycle as it plays a role in plant-water relations and regulation of ionic balances within cells. The superior response in uptake of $\mathrm{Ca}, \mathrm{Mg}$ and $\mathrm{K}$ due to $10 \%$ Al-WTR $+10 \% \mathrm{C}+\mathrm{P}$ over standard NPK showed that a combination of Al-WTR + compost $+\mathrm{P}$ can be used as an alternative of the standard farming practice without any negative implications for uptake of $\mathrm{Ca}, \mathrm{Mg}$ and $\mathrm{K}$. Evidence has shown that a decline in the exchangeable basic cations leads to a decrease in maize yields (Mtangadura et al., 2017).

The relatively high uptake of $\mathrm{Zn}$ in the coamendment was within optimal limits for maize production. $\mathrm{Zn}$ concentrations in maize plant tissue of between 20 and $60 \mathrm{ppm}$ are considered sufficient (Tandon 1993). Deficiencies of $\mathrm{Zn}$ have been reported in African soils (Tagwira 1993; Manzeke et al., 2014; Kihara et al., 2020). Some studies have shown that integrated nutrient management including application of organic nutrient resources can increase plant $\mathrm{Zn}$ concentration (Manzeke et al., 2014; Yang et al., 2007); thus, WTR could potentially supply Zn in sandy soils (Dayton \& Basta, 2001; Titshall \& Hughes, 2005). The concentration of $\mathrm{Cu}$ in maize plant tissue due to the co-amendment was also well within the recommended limits of $300 \mathrm{ppm}$. From these results, Al-WTR can therefore supply safe levels of $\mathrm{Cu}$. Although copper is required in minute quantities, it is important in plants for many enzymatic 
processes. The study also revealed that $10 \% \mathrm{Al}-$ $\mathrm{WTR}+10 \% \mathrm{C}+\mathrm{P}$ also enhanced Mn uptake by maize and that $\mathrm{Pb}, \mathrm{Ni}$ and $\mathrm{Al}$ were all well below the threshold toxicity levels in maize plant tissue (Tandon 1993), signifying that compost and Al-WTR can be safely used as a soil amendment for maize growth without causing heavy metal toxicity. Based on these results, Al-WTR could complement other organic nutrient resources to supply micronutrients to the soil for plant uptake. The supply of micronutrients for plant uptake is important, given that micronutrient deficiencies are widespread in SSA arable soils (Kihara et al., 2020). This has great implications for human health - the high nutritional quality of edible plant organs improves human nutrition (Kihara et al., 2020; Yang et al., 2007). Improved human nutrition is important in Africa, given that over 200 million people are undernourished (FAO et al., 2018).

\section{Conclusion}

The study demonstrated the superiority of combining Al-WTR and compost with P fertilizer in enhancing uptake of $\mathrm{Zn}, \mathrm{Cu}$ and $\mathrm{Mn}$ by maize, which could provide an entry point for alleviating micronutrient deficiency in cereal-based diets in SSA. The study also showed that co-application of Al-WTR and compost together with the addition of inorganic $\mathrm{P}$ improved nutrient uptake, growth and dry matter yield of maize. The results also indicated reduced heavy metal $(\mathrm{Pb}$, $\mathrm{Ni}, \mathrm{Al}$ ) uptake by the cereal crop in comparison with the unamended control, sole Al-WTR, sole compost treatments and standard NPK. There was also a decrease in post-harvest heavy metal content in soils co-amended with a combination of compost and AlWTR relative to sole Al-WTR treatments. The significant increase in soil $\mathrm{pH}$ due to the co-amendment proved essential in decreasing bioavailability of heavy metals such as $\mathrm{Pb}$ and $\mathrm{Ni}$ and to reduce $\mathrm{Al}$ toxicity, which can be problematic in sandy soils. Overall, the study revealed that WTR can be co-applied with another organic nutrient resource such as compost for improved soil health (measured in terms of decreased bioavailability of potentially toxic elements $\mathrm{Pb}, \mathrm{Ni}$ and $\mathrm{Al}$ ) and increased crop production and environmental protection. We concluded that Al-WTR adds to the suite of available organic nutrient resources and can be co-applied with compost and mineral fertilizers to enhance soil quality and associated crop growth presenting a plausible alternative for re-using the product for soil improvement. Further research should investigate optimal inorganic $\mathrm{P}$ application rates to offset the negative effects of Al-WTR in P fixation as well as testing its agronomic benefits in field experiments.

Acknowledgements We acknowledge funding from Durham University's Global Challenges Research Fund (GCRF) for the project 'Soil health improvement technologies to enhance drought and nutrient resilience in Zimbabwean soils' and the Geography Department, Durham University, for laboratory analysis and David Brookes for the help in sourcing WTR. We also acknowledge the University of Zimbabwe for providing technical support.

Funding This study was funded through Durham University's Global Challenges Research Fund (GCRF).

\section{Declarations}

Conflict of interest The authors declare that they have no conflict of interest.

Open Access This article is licensed under a Creative Commons Attribution 4.0 International License, which permits use, sharing, adaptation, distribution and reproduction in any medium or format, as long as you give appropriate credit to the original author(s) and the source, provide a link to the Creative Commons licence, and indicate if changes were made. The images or other third party material in this article are included in the article's Creative Commons licence, unless indicated otherwise in a credit line to the material. If material is not included in the article's Creative Commons licence and your intended use is not permitted by statutory regulation or exceeds the permitted use, you will need to obtain permission directly from the copyright holder. To view a copy of this licence, visit http://creativecommons.org/licenses/by/4.0/.

\section{References}

Ahmad, T., Ahmad, K., \& Alam, M. (2016). Sustainable management of water treatment sludge through 3 'R' concept. Journal of Cleaner Production, 124, 1-13.

American Society of Civil Engineers, American Water Works Association, and the USEPA. (1996). Technology transfer handbook: Management of water treatment plant residuals.

Anderson, J. M., \& Ingram, J. S. I. (1993). Tropical soil biology and fertility: A handbook of methods (2nd ed.). C.A.B International.

Awad, A. (2019). Economic globalisation and youth unemployment-evidence from African countries. International Economic Journal, 33(2), 252-269.

Babatunde, A. O., \& Zhao, Y. Q. (2010). Equilibrium and kinetic analysis of phosphorus adsorption from aqueous 
solution using waste alum sludge. Journal of Hazardous Materials, 184(1-3), 746-752.

Babatunde, A. O., Zhao, Y. Q., Yang, Y., \& Kearney, P. (2008). Reuse of dewatered aluminium-coagulated water treatment residual to immobilize phosphorus: Batch and column trials using a condensed phosphate. Chemical Engineering Journal, 136(2-3), 108-115.

Bai, L., Wang, C., He, L., \& Pei, Y. (2014). Influence of the inherent properties of drinking water treatment residuals on their phosphorus adsorption capacities. Journal of Environmental Sciences, 26(12), 2397-2405.

Basta, N. T. (2000). Examples and case studies of beneficial reuse of municipal by products. Land Application of Agricultural, Industrial, and Municipal by Products, 6, 481-504.

Bonifas, K. D., Walters, D. T., Cassman, K. G., \& Lindquist, J. L. (2005). Nitrogen supply affects root: shoot ratio in corn and velvet leaf (Abutilon theophrasti). Weed Science, 53, 670-675.

Clarke, C. E., Stone, W., Hardie, A. G., Quinton, J. N., Blake, L. I., \& Johnson, K. L. (2019). Better together: Water treatment residual and poor-quality compost improves sandy soil fertility. Journal of Environmental Quality, 48(6), 1781-1788. https://doi.org/10.2134/jeq2019.03.0147

Clemente, R., \& Bernal, M. P. (2006). Fractionation of heavy metals and distribution of organic carbon in two contaminated soils amended with humic acids. Chemosphere, 64(8), 1264-1273.

Cockx, L., Colen, L., \& De Weerdt, J. (2018). From corn to popcorn? Urbanization and dietary change: Evidence from rural-urban migrants in Tanzania. World Development, 110, 140-159.

Cox, A. E., Camberato, J. J., \& Smith, B. R. (1997). Phosphate availability and inorganic transformation in an alum sludge affected soil (Vol. 26, No. 5, pp. 1393-1398). American Society of Agronomy, Crop Science Society of America, and Soil Science Society of America.

Dassanayake, K. B., Jayasinghe, G. Y., Surapaneni, A., \& Hetherington, C. (2015). A review on alum sludge reuse with special reference to agricultural applications and future challenges. Waste Management, 38, 321-335.

Dayton, E. A., \& Basta, N. T. (2001). Characterization of drinking water treatment residuals for use as a soil substitute. Water Environment Research, 73(1), 52-57.

Elliott, H. A., \& Dempsey, B. A. (1991). Agronomic effects of land application of water treatment sludges. Journal American Water Works Association, 83(4), 126-131.

Elliott, H. A., Dempsey, B. A., Hamilton, D. W., \& DeWolfe, J. R. (1990) Land application of water treatment sludges. Final Report AWWARF: Denver, CO.

Ericsson, T. (1995). Growth and shoot: root ratio of seedlings in relation to nutrient availability. In Nutrient uptake and cycling in forest ecosysytems (pp. 205-214). Dordrecht: Springer.

Eskilsson, C. S., \& Björklund, E. (2000). Analytical-scale microwave-assisted extraction. Journal of Chromatography A, 902(1), 227-250.

FAO, I. ISSS. (1998). World reference base for soil resources. 84 .
FAO, IFAD, UNICEF, WFP, \& WHO. (2018). The state of Food Security and Nutrition in the World 2018. Building climate resilience for Food Security and Nutrition. FAO, 202pp

FAO/WHO, Codex Alimentarius Commission (2001) Food additives and contaminants. Joint FAO/WHO food standards programme, ALINORM 01/12A:1-289

Food and Agriculture Organisation (FAO). (2019). FAOSTAT Statistical Database of the United Nation Food and Agriculture Organisation (FAO) Statistical Division.

Fitton, G. (1997). X-ray fluorescence spectrometry. In Modern analytical geochemistry: an introduction to quantitative chemical analysis for earth, environmental and material scientists: Addison Wesley Longman, UK.

Geertsema, W. S., Knocke, W. R., Novak, J. T., \& Dove, D. (1994). Long-term effects of sludge application to land. Journal of American Water Works Association, 86(11), 64-74.

Gibbons, M. K., \& Gagnon, G. A. (2011). Understanding removal of phosphate or arsenate onto water treatment residual solids. Journal of Hazardous Materials, 186(2-3), 1916-1923.

Grabarek, R. J., \& Krug, E. C. (1987). Silvicultural application of alum sludge. Journal-American Water Works Association, 79(6), 84-88.

Hastings, E., \& Dawson, J. J. C. (2012). The use of alum sludge and sewage sludge as a soil improver on Barra-further response. CREW Publication, Call Down Project (CD2012/16).

Havlin J. L., Beaton J. D., Tisdale S. L., \& Nelson, W. L. (2005). Soil fertility and Fertilizers: an introduction to nutrient management (7th ed.). Upper Saddle River, N.J.: Pearson Prentice Hall.

Heil, D. M., \& Barbarick, K. A. (1989). Water treatment sludge influence on the growth of sorghum-sudangrass. Journal of Environmental Quality, 18(3), 292-298.

Hovsepyan, A., \& Bonzongo, J. C. J. (2009). Aluminium drinking water treatment residuals (Al-WTRs) as sorbent for mercury: Implications for soil remediation. Journal of Hazardous Materials, 164(1), 73-80.

Hsu, W. M., \& Hseu, Z. Y. (2011). Rehabilitation of a sandy soil with aluminium-water treatment residual. Soil Science, 176(12), 691-698.

Hyde, J. E., \& Morris, T. F. (2004). Phosphorus availability from phosphorus-amended water treatment residual. Communications in Soil Science and Plant Analysis, 35(7-8), 1033-1046.

Ippolito, J. A. (2015). Aluminum-based water treatment residual use in a constructed wetland for capturing urban runoff phosphorus: Column study. Water, Air, and Soil Pollution, 226(10), 1-8.

Jonasson, B. (1996). Phosphorus transformation in alum sludge amended soils. Swedish Journal of Agricultural Research, $26,69$.

Kamanga, B. C. G., Waddington, S. R., Whitbread, A. M., Amelkinders, C. J. M., \& Giller, K. E. (2014). Improving the efficiency of use of small amounts of nitrogen and phosphorus fertilizer on smallholder maize in central Malawi. Experimental Agriculture, 50(2), 229-249.

Keesstra, S. D., Bouma, J., Wallinga, J., Tittonell, P., Smith, P., Cerdà, A., et al. (2016). The significance of soils and soil 
science towards realization of the United Nations sustainable development goals. The Soil, 2(2), 111-128.

Kihara, J., Bolo, P., Kinyua, M., Rurinda, J., \& Piikki, K. (2020). Micronutrient deficiencies in African soils and the human nutritional nexus: Opportunities with staple crops. Environmental Geochemistry and Health. https://doi.org/10. 1007/s10653-019-00499-w

Kögel-Knabner, I., Guggenberger, G., Kleber, M., Kandeler, E., Kalbitz, K., Scheu, S., et al. (2008). Organo-mineral associations in temperate soils: Integrating biology, mineralogy, and organic matter chemistry. Journal of Plant Nutrition and Soil Science, 171(1), 61-82.

Kutiwa, S., Boon, E., \& Devuyst, D. (2010). Urban agriculture in low income households of Harare: An adaptive response to economic crisis. Journal of Human Ecology, 32(2), 85-96.

Lal, R. (2019). Promoting " 4 per thousand" and "adapting African agriculture" by south-south cooperation: Conservation agriculture and sustainable intensification. Soil and Tillage Research, 188, 27-34.

Lucas, J. B., Dilaha, T. A., Reneau, R. B., Novak, J. T., \& Knocke, W. R. (1994). Alum sludge land application and its effect on plant growth. Journal-American Water Works Association, 86(11), 75-83.

Mahdy, A. M., Elkhatib, E. A., \& Fathi, N. O. (2007). Drinking water treatment residuals as an amendment to alkaline soils: Effects on the growth of corn and phosphorus extractability. International Journal of Environmental Science and Technology, 4(4), 489-496.

Malhotra, H., Sharma, S., \& Pandey, R. (2018). Phosphorus nutrition: plant growth in response to deficiency and excess. In Plant Nutrients and Abiotic Stress Tolerance (pp. 171-190). Singapore: Springer

Manitoba Crop Reports. Accessed 16 December 2020 from https://www.gov.mb.ca/agriculture/crops/seasonal-reports/ pubs/staging-corn-correctly.pdf.

Manzeke, G. M., Mapfumo, P., Mtambanengwe, F., Chikowo, R., Tendayi, T., \& Cakmak, I. (2012). Soil fertility management effects on maize productivity and grain zinc content in smallholder farming systems of Zimbabwe. Plant and Soil, 361(1-2), 57-69.

Manzeke, G. M., Mtambanengwe, F., Nezomba, H., \& Mapfumo, P. (2014). Zinc fertilization influence on maize productivity and grain nutritional quality under integrated soil fertility management in Zimbabwe. Field Crops Research, 166, 128-136.

Mapfumo, P., \& Giller, K.E. (2001). Soil Fertility Management Strategies and Practices by Smallholder Farmers in SemiArid Areas of Zimbabwe. ICRISAT/FAO.

Matilainen, A., Vepsäläinen, M., \& Sillanpää, M. (2010). Natural organic matter removal by coagulation during drinking water treatment: A review. Advances in Colloid and Interface Science, 159(2), 189-197.

Mtambanengwe, F., \& Mapfumo, P. (2005). Organic matter management as an underlying cause for soil fertility gradients on smallholder farms in Zimbabwe. Nutrient Cycling in Agroecosystems, 73(2), 227-243.

Mtambanengwe, F., \& Mapfumo, P. (2006). Effects of organic resource quality on soil profile $\mathrm{N}$ dynamics and maize yields on sandy soils in Zimbabwe. Plant and Soil, 281(1-2), 173-191.
Mtambanengwe, F., \& Mapfumo, P. (2009). Combating food insecurity on sandy soils in Zimbabwe: The legume challenge. Symbiosis, 48, 25-36.

Mtangadura, T. J., Mtambanengwe, F., Nezomba, H., Rurinda, J., \& Mapfumo, P. (2017). Why organic resources and current fertilizer formulations in Southern Africa cannot sustain maize productivity: Evidence from a long-term experiment in Zimbabwe. PloS One, 12(8), e0182840.

Nezomba, H., Mtambanengwe, F., Tittonell, P., \& Mapfumo, P. (2015). Point of no return? Rehabilitating degraded soils for increased crop productivity on smallholder farms in eastern Zimbabwe. Geoderma, 239-240, 143-155.

Norris, N., \& Titshall, L. W. (2012). The distribution of inherent phosphorus in fifteen water treatment residues from South Africa. Water SA, 38, 715-720.

Novak, J. M., \& Watts, D. W. (2004). Increasing the phosphorus sorption capacity of Southeastern Coastal Plain soils using water treatment residuals. Soil Science, 169(3), 206-214.

Nyamangara, J., \& Mpofu, S. E. (1996). Soil pH and lime requirement for high potential communal areas of Zimbabwe. Journal of Applied Science in Southern Africa, 2(2), 77-81.

Nyamangara, J., Mugwira, L. M., \& Mpofu, S. E. (2000). Soil fertility status in the communal areas of Zimbabwe in relation to sustainable crop production. Journal of Sustainable Agriculture, 16(2), 15-29.

Nyamapfene, K. W. (1991) The soils of Zimbabwe (Vol. 1). Nehanda Publishers.

Nyamasoka, B., Nyamugafata, P., Madyiwa, S., \& Nyamangara, J. (2015). Urban farmer practices in soil fertility and water management and the influence of gender in Harare and Chitungwiza, Zimbabwe. African Journal of Agricultural Research, 10(3), 100-107.

Olsen, S. R. (1954) Estimation of available phosphorus in soils by extraction with sodium bicarbonate (No. 939). US Department of Agriculture.

Pais, I., \& Jones, J. B., Jr. (1997). The handbook of trace elements. CRC Press.

Rengasamy, P., Oades, J. M., \& Hancock, T. W. (1980). Improvement of soil structure and plant growth by addition of alum sludge. Communications in Soil Science and Plant Analysis, 11(6), 533-545.

Rurinda, J., Zingore, S., Jibrin, J. M., Balemi, T., Masuki, K., Andersson, J. A., et al. (2020). Science-based decision support for formulating crop fertiliser recommendations in sub-Saharan Africa. Agricultural Systems, 180, 102790.

Rurinda, J., van Wijk, M. T., Mapfumo, P., Descheemaeker, K., Supit, I., \& Giller, K. E. (2015). Climate change and maize yield in southern Africa: What can farm management do? Global Change Biology, 21(12), 4588-4601.

Tagwira, F., Piha, M., \& Mugwira, L. (1993). Zinc distribution in Zimbabwean soils and its relationship with other soil factors. Communications in Soil Science and Plant Analysis, 24(9-10), 841-861.

Takavarasha T. (2003) Urban Agriculture in Harare. Paper presented at the Minister's Conference on Urban and Peri-urban Agriculture in Eastern and Southern Africa: Prospects for Food Security and Growth, Harare, 28-29 August 2003.

Tandon H. L. S. (1993). Methods of analysis of soils, plants, waters and fertilizers. India: Fertilizer Development and Consultation Organisation. 
Tilman, D. (1985). The resource-ratio hypothesis of plant succession. American Naturalist, 125, 827-852.

Titshall, L. W., \& Hughes, J. C. (2005). Characterisation of some South African water treatment residues and implications for land application. Water SA, 31(3), 299-308.

Tóth, G., Hermann, T., Da Silva, M. R., \& Montanarella, L. (2016). Heavy metals in agricultural soils of the European Union with implications for food safety. Environment International, 88, 299-309.

Vanlauwe, B., Bationo, A., Chianu, J., Giller, K. E., Merckx, R., Mokwunye, U., et al. (2010). Integrated soil fertility management: Operational definition and consequences for implementation and dissemination. Outlook on Agriculture, 39(1), 17-24.

World Health Organization (1996). Trace elements in human nutrition and health. World Health Organization.
World Reference Base (2006). IUSS Working Group World reference base for soil resources. World Soil Resources Reports No. 103. Rome: Food and Agriculture Organization (FAO). 2006.

Yang, X. E., Chen, W. R., \& Feng, Y. (2007). Improving human micronutrient nutrition through biofortification in the soilplant system: China as a case study. Environmental Geochemistry and Health, 29(5), 413-428.

Zingore, S., Mutegi, J., Agesa, B., Desta, L. T., \& Kihara, J. (2015). Soil degradation in Sub-Saharan Africa and crop production options for soil rehabilitation. Better Crops with Plant Food, 99(1), 24-26.

Publisher's Note Springer Nature remains neutral with regard to jurisdictional claims in published maps and institutional affiliations. 